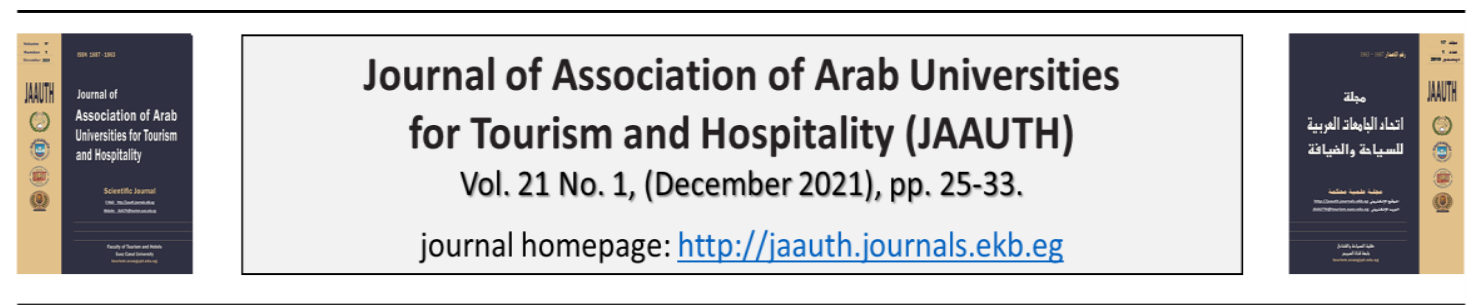

\title{
Reused Pharaonic blocks in Cairo Islamic monuments: Part two
}

\begin{tabular}{|c|c|}
\hline \multicolumn{2}{|c|}{$\begin{array}{c}\text { Haitham T. Sotohy } \\
\text { Assistant professor of Tour Guiding, Tour Guiding Department, Higher Institute for } \\
\text { Tourism and Hotels (EGOTH) at Luxor. }\end{array}$} \\
\hline ARTICLE INFO & ABSTRACT \\
\hline $\begin{array}{l}\text { Keywords: } \\
\text { Pharaonic blocks; } \\
\text { Cairo Islamic } \\
\text { monuments; } \\
\text { Ramesses IX, } \\
\text { Senwosert I; } \\
\text { Heliopolis. }\end{array}$ & $\begin{array}{l}\text { This paper is the second part of the study of some reused } \\
\text { Pharaonic blocks in Cairo Islamic monuments. These blocks } \\
\text { are mostly unpublished. The studied blocks are the threshold } \\
\text { in Khanqah-Mausoleum of Sultan Baybars AL Jashankir, the } \\
\text { text on this block dates to the time of Ramesses IX. The } \\
\text { second block is the threshold in Gateway of Wekala of } \\
\text { Qusoun, the text on this block dates to the time of Ramesses } \\
\text { II. The third block is the threshold in Ahmed Ibn Shaaban } \\
\text { Zawia, which dates to the time of Senwosert. The fourth } \\
\text { block is the threshold in Othman Katkhoda (Kekhya) } \\
\text { mosque, this block was noted by Daressy, and he thought it is } \\
\text { a part of a Saite period sarcophagus lid. The provenance of } \\
\text { these blocks could be suggested according to the texts on } \\
\text { each of them. According to the study of these blocks, } \\
\text { Heliopolis is the provenance of most of them. }\end{array}$ \\
\hline
\end{tabular}

\section{Introduction}

Many scholars referred to the reused Pharaonic blocks in Cairo Islamic monuments (Creswell1952, 195-196; Williams2008, 207; Harrell, Lazzarini and Bruno 2000; A Wahab 1946). Scholars thought that they were mainly transported from Memphis and Heliopolis (Meinecke-Berg V. 1982, D. Heiden 2001, D. Heiden 2002; Postel and Regen 2005, Postel and Regen 2006). Others considered these blocks were not only intended to be just used as building materials, but also, they bear a talismanic meaning (Behrens-Abouseif 1989, 106).

The first part of this study was published in 2011(Sotohy 2011) when the author studied some reused blocks in Cairo Islamic monuments. New reused blocks were noted by the author after the publication of the first part of the study. This second part of the study is the study of new blocks in some Islamic monuments; these blocks are mostly unpublished. The blocks of the present study are: the threshold in KhanqahMausolum of Sultan Baybars AL Jashankir, the threshold in Gateway of Wekala of Qusoun, the threshold in Ahmed Ibn Shaaban Zawia, and the threshold in Othman Katkhoda (Kekhya) mosque. Those blocks still bear inscription give details about their Pharaonic owners, and the provenance of each block can be suggested according to the information given in the text. 


\section{Block One: Khanqah-Mausolum of Sultan Baybars AL Jashankir}

The Khanqah of Baybars AL Jashankir locates in Jamaliyya quarter; monument no. 32. It dates to the Bahri Mamluks period (1307-1310) (Behrens-Abouseif 1989, 104). The door threshold is Pharaonic red granite reused block (Fig 1) (BehrensAbouseif 1989, 106).

The scenes on the threshold shows a king represented three times in adoration pose. The first register the king is represented kneeling in adoration position and wears hprs crown.

A text written under him reads:

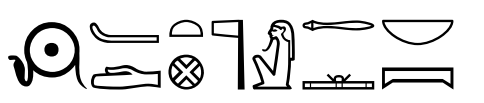

Bhdty $n t r ~ 3 n b p t$ The Behdetite, the great god, lord of heaven.

A column of two $f_{n h}$ signs between them there is one $\hat{h} w 3 s$ sign, a traditional formula read anx $w 3 s$ "life and stability" related to the royal representations.

The second figure the king kneeling in the same position and wears $h 3 t$ headdress, and the same text is repeated under him:

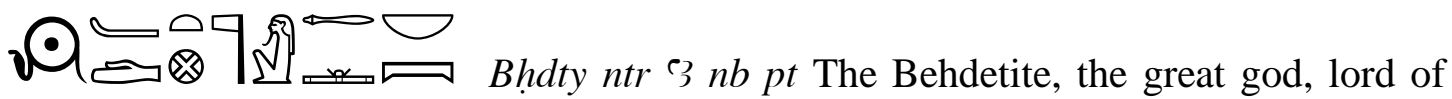
heaven.

The third figure, the king kneeling in the same position and wears $n m s$ headdress. The name of the king inscribed under him as $n f r k 3 R^{\complement}$ stp $n R^{\ulcorner}$Neferkare

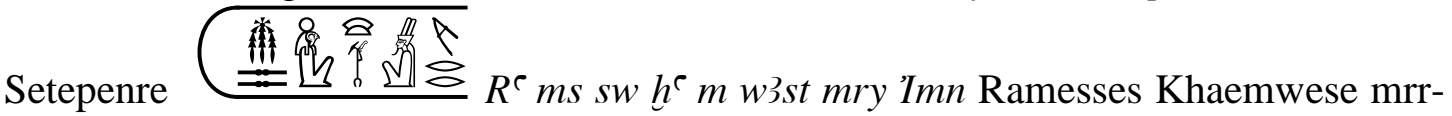
Imn. These are the coronation and birth name of Ramesses IX (Beckerath 1999, 17273; Leprohon 2013, 133).

Ramesses IX is represented here in adoration pose, that may this block was once a part of a temple or religious building for this king. The provenance of this piece may be Heliopolis that Ramesses IX main works were at Heliopolis (Kitchen 1984, 125). Fragments of a statue and offering table were found for the king in Heliopolis (KRI, VI 449-450).

The text refers to the god Horus of Behdety, or the Behdetite, a representation always found on the top of such religious scenes. The god Horus the Behdetite and his city Edfu had a relation with Heliopolis (Cauville 2001, 438). It is not strange to find a representation of Horus the Behdetite connected to Heliopolis.

\section{Block two: Gateway of Wekala of Qusoun}

Wekala of Qusoun locates in Bab El Nasr street in El Jamaliyya quarter; monument no. 11. It dates to the Bahari Mamluks period $1341 \mathrm{AD}$. The only remaining part of the Wekala is its gateway. 
The threshold in the gateway of Wekala is a Pharaonic red granite reused stone (Fig 2). The text on the threshold reads:

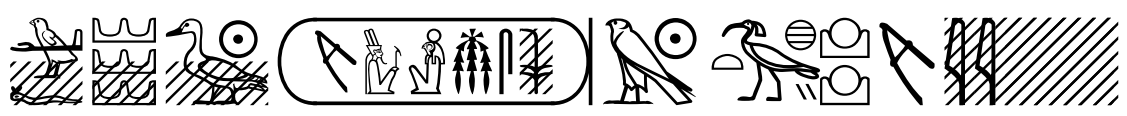

$w^{\complement}[f] h 3 s[w t] s 3 r^{e}\left(R^{e}-m s-s w\right.$ mry-Imn) mry $R^{e}-H r$-3hty

Who has subdued the foreign lands, Son of Re (Ramesses Mreiamun), beloved of Re-Horakhty (Lorand 2013, 272; LGG IV, 360).

The block dates to the time of Ramesses II, as part of his titular still can be read on it (Beckerath 1999, 152-57; Leprohon 2013, 114). The title link the king to the Heliopolitan god Re-Horakhty as mry $R^{\top}-h r$-3hty beloved of Re-Horakhty. This makes it sure that the provenance of this piece is Heliopolis.

Ramesses II had certain building activities in Heliopolis in the great temple of Re there (RITANC II, 339-340). Fragments and stela link him to Re-Horakhty were found there (PM IV, 60-61; KRI II, 484). On the stela from Heliopolis the king is represented dedicating an obelisk to Re-Horakhty (KRI II, 484). All these evidence refer to Heliopolis as the provenance of this reused block.

\section{Block Three: Ahmed Ibn Shaaban Zawia:}

Ahmed Ibn Shaban Zawia locates in Batnia street in El Azhar area, monument no. 103. It dates to the Othman period $16^{\text {th }}$ century AD. The threshold of the door is a red quartzite reused Pharaonic block (Fig 3). Inscription on the block reads:

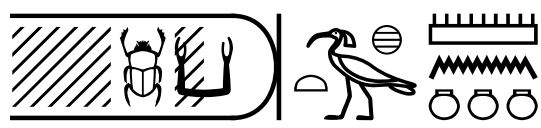

(hpr k3 [rf]) 3ht mnw

Kheper-ka-[re] glorious monument

The remaining part of the cartouche shows the $h p r$ sign and part of the $\sqcup_{k 3 \text { sign }}$ could be seen. Three ancient Egyptian kings use the $h p r$ and $k 3$ sign in their throne names; Senwosert I hpr-k3-r' (Beckerath 1999, 82-83) and Thutmosis I $3-h p r-k 3-r^{c}$ (Beckerath 1999, 132-35) and Nectanebo I hpr-k3-r (Beckerath 1999, 226-227). It is more probable that the name here is the name of Senwosert I because the remaining

part in the cartouche just fit for one more sign which is the $\odot r^{\mathrm{c}}$ sign.

This block was noted by Daressy, and he attributed it to Senwosert I (Daressy 1908, 139). Senwosert has building activities nearby in Heliopolis, where there is his famous obelisk (PM IV, 60; Simpson 1984, 892). The provenance of this block may be Heliopolis. For Senwosert I another block was found reused as a threshold in El Azhar area near Ahmed Ibn Shaaban Zawia, and it was transmitted to the Egyptian museum by Daressy (Daressy 1903, 101).

There is a second upper part of the threshold, which is another reused sandstone Pharaonic block with traces of unclear scene represents in the upper register a cow 
behind it may be a shape like an obelisk, in the second register there are two seated men. The remaining part of the stone the scenes is completely erased.

\section{Block Four: Othman Katkhoda (Kekhya) mosque}

The mosque of Othman Katkhuda locates in Opera square in Azbakiyya, monument no. 264. It dates to the Othman period 1734 AD (Behrens-Abouseif 1989, 164). In The vaulted portal in the façade of the mosque the threshold is a black granite reused Pharaonic block (Fig 4). There are traces of 4 column hieroglyphic text on the threshold. The remaining parts of the texts are:

Beginning of the first column the text reads
the", at the end of the first column the remaining text reads $n$ mht.f shn "to fill the content of". The beginning of the second column reads 7970

ntrw $m$ hwt "Gods of the temple", at the end of the second column the

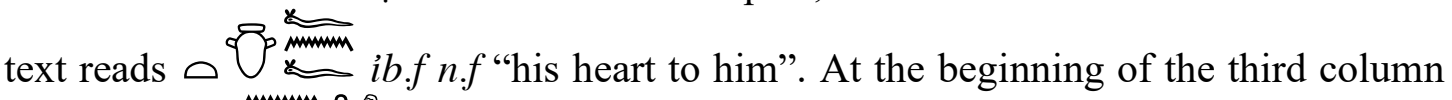

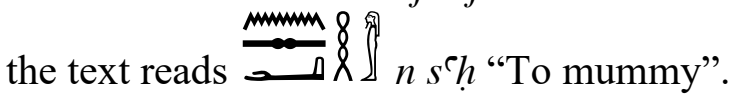

This block was noted by Daressy; and he though it is a part of a Saite period sarcophagus lid. At his time Daressy could read the now erased text and attributed it to the chapter 8 of the Book of the Dead (Daressy 1908, 139). Unfortunately, Daressy didn't copy the text which was clear at his time nor he gave a photo of the block. Daressy could read the titles of the owner as 过 imy-r š́ hnty pr-wr "Osiris, controller of the building, scribe of the per-wr (Great house; the sanctuary of Upper Egypt) (Daressy 1908, 139; Gardiner 1944, 27, note 3). The remaining part of the text on this block now gives no complete meaning, but the text is of funerary nature according to the meaning of some words, which support the opinion of Daressy. The use of the sign in the first column suggest a New Kingdom or later dating, because this sign had been rarely be used before the $18^{\text {th }}$ dynasty (Gardiner 1957, 504). The provenance of this block can't be suggested.

\section{Conclusion}

Four reused Pharaonic blocks are studied in this paper, which is the study of the blocks: the threshold in Khanqah-Mausolum of Sultan Baybars AL Jashankir, on it there is a scene and text dates to Ramesses IX represented in adoration pose, with the god Horus Behdety. The provenance of this piece may be Heliopolis. The second block is the threshold in Gateway of Wekala of Qusoun, dates to the time of Ramesses II, as part of his titular still can be read on it. The king is titled "beloved of Re-Horakhty". This makes it sure that the provenance of this piece is Heliopolis. The third block is the threshold in Ahmed Ibn Shaaban Zawia, dates to the time of Senwosert I. The provenance of this block must be Heliopolis. Another block is found there but the text and scenes on this second block of Ahmed Ibn Shaaban Zawia is erased now. The fourth block is the threshold in Othman Katkhoda (Kekhya) mosque. 
This block was noted by Daressy; and he though it is a part of a Saite period sarcophagus lid. The remaining part of the text on this block now gives no complete meaning, but the text is of funerary nature according to the meaning of some words. The provenance of this block can't be suggested.

\section{Figures}
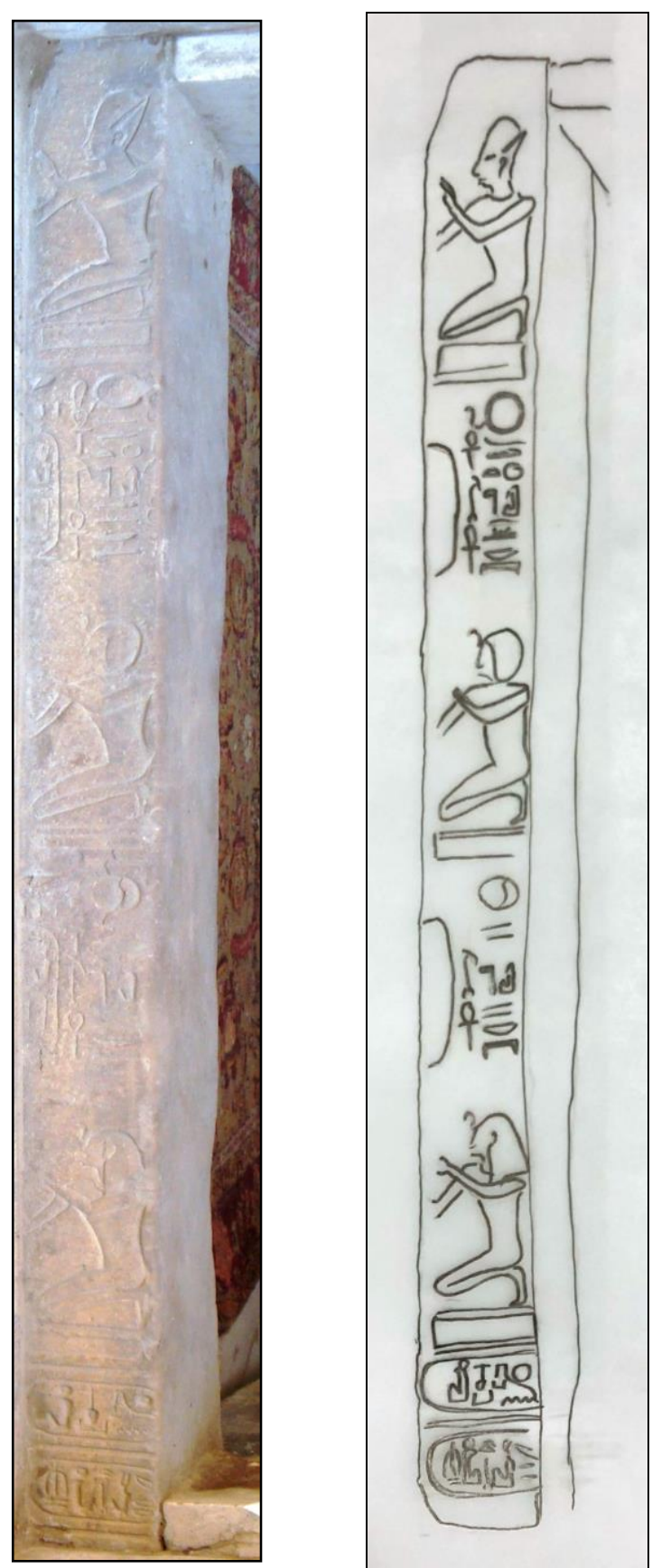

Fig.1. threshold o Khanqah-Mausolum of Sultan Baybars AL Jashankir

Meinecke-Berg V. 1982. SDAIK 18; Cairo, 1985), 133, 135, pl. 12c.

Photo by the author 

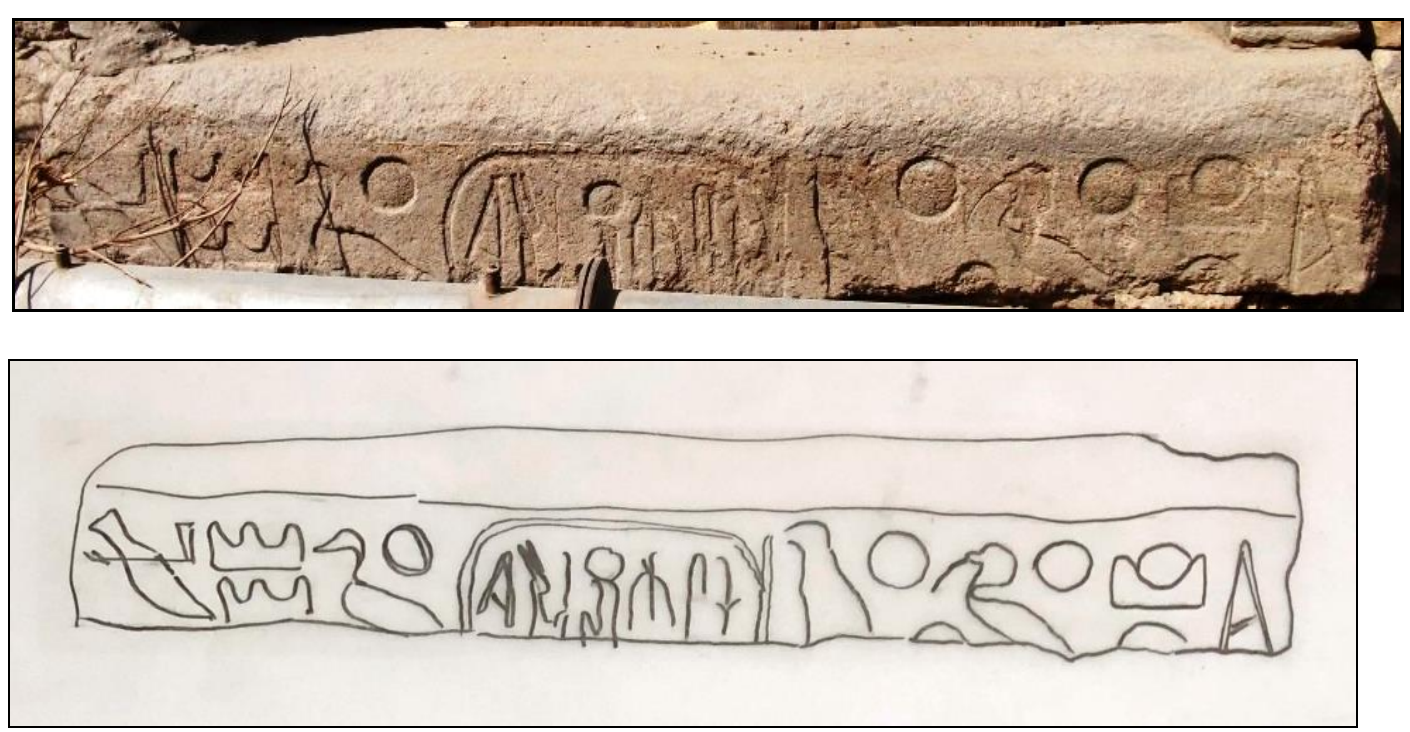

Fig.2. The threshold in the gateway of Wekala of Qusoun Lorand D. 2013, JEA 99, 270.

Photo by the author
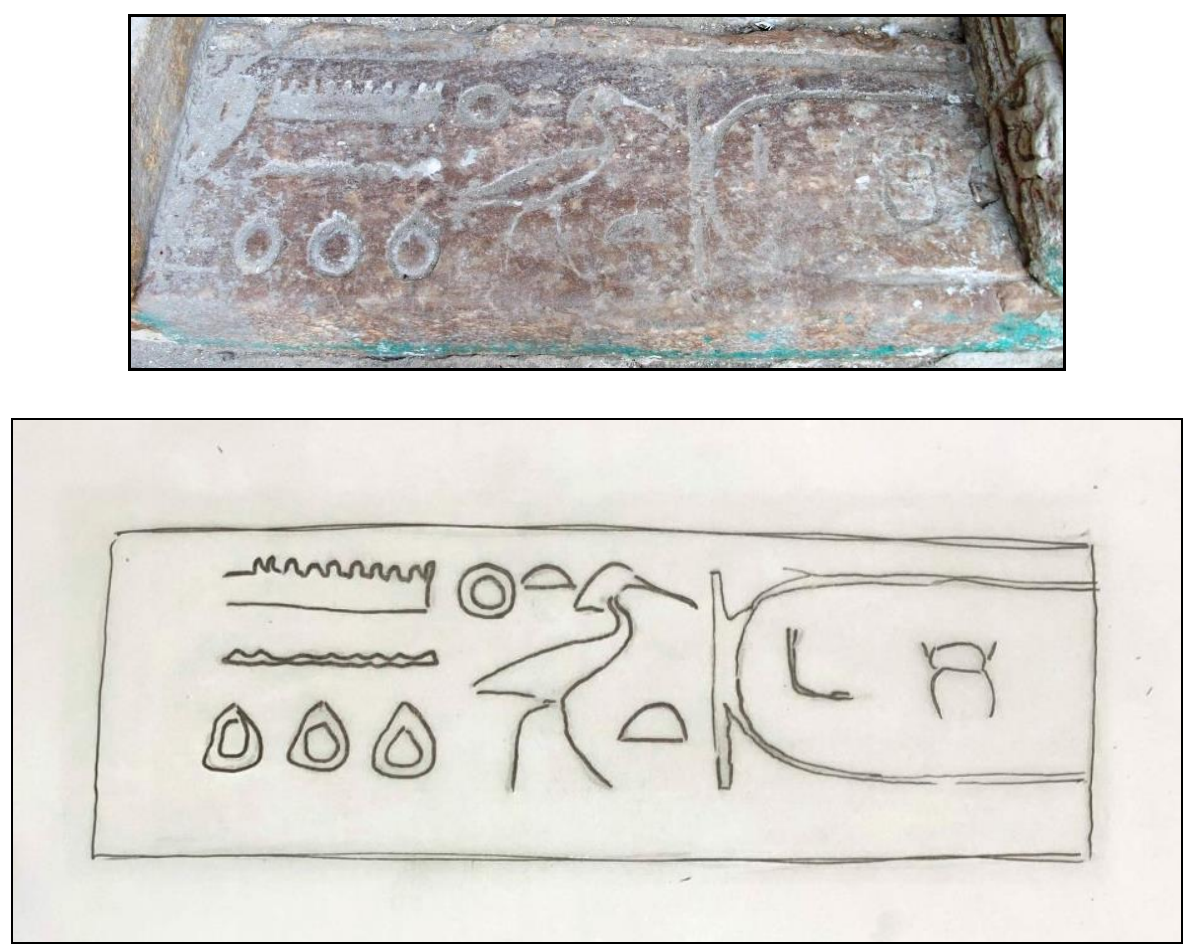

Fig.3. The threshold of Ahmed Ibn Shaban Zawia Daressy 1908. ASAE 9, 139.

Photo by the author 

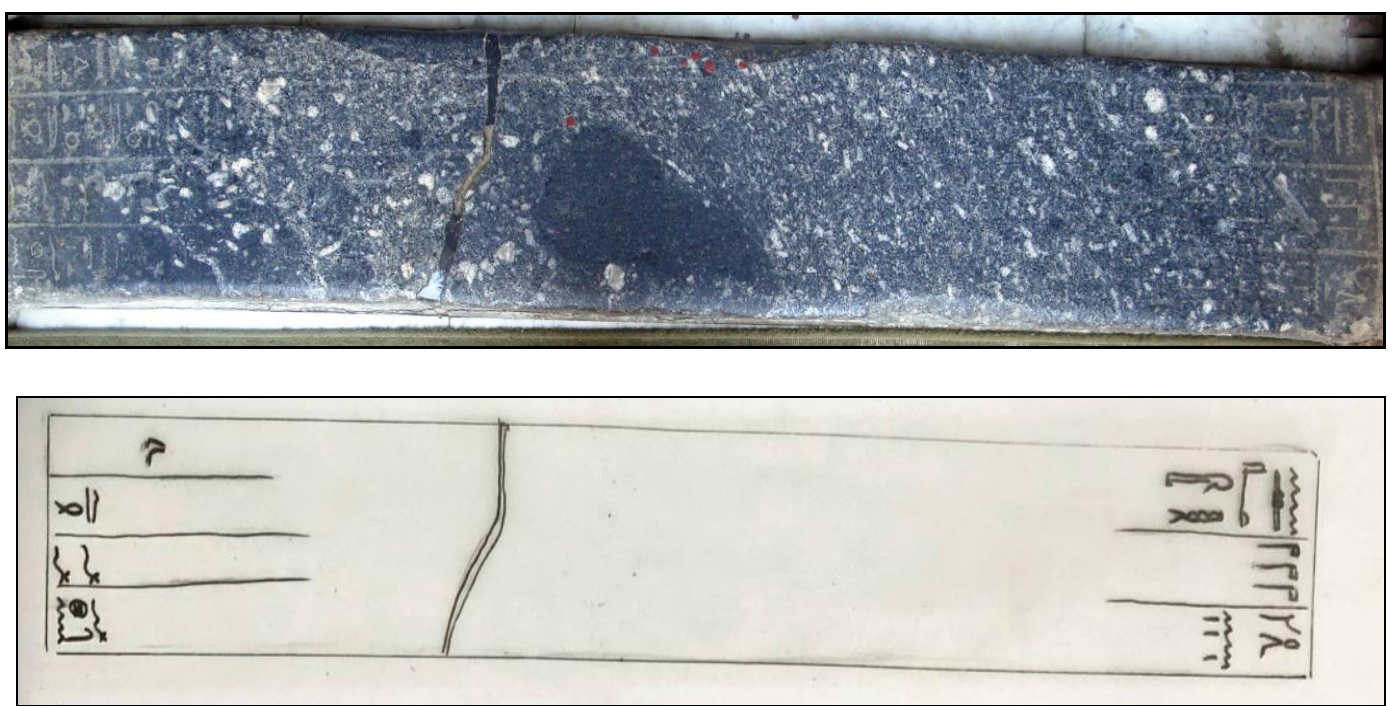

Fig.4. the threshold Othman Katkhoda (Kekhya) mosque

Daressy 1908. ASAE 9, 140.

Photo by the author

\section{Bibliography}

- A Wahab,H. (1946), Tarikh Al Masajied Al Atharea, Cairo,132.

- Beckerath, Jürgen von. 1999. Handbuch der ägyptischen Königsnamen. MÄS 20. Munich and Berlin: Deutscher Kunstverlag.

- Behrens-Abouseif, D., (1989), Islamic Architecture in Cairo, Leiden, 78.

- The Aga Khan trust for culture, the eastern Ayyubid wall of Cairo, Reused Pharaonic stones, Cairo, no date.

- Cauville S. 2001. Edfu In Oxford Encyclopedia of Ancient Egypt II, 436-438.

- Creswell, K. A. C., (1952), The Muslim Architecture of Egypt. Vol. I - Ikhshids and Fatimids, A.D. 939-1171: Oxford.

- Daressy 1903. Inscription Hiéroglyphique trouve dans le Caire, ASAE 4, 101-103.

- Daressy 1908. Note sur pierres antiques du Caire. ASAE 9, 139-140.

- Gardiner A. 1957. Egyptian Grammar, being an introduction to the study of Hieroglyphs. $3^{\text {rd }}$ edition, Oxford.

- Gardiner A. 1944. Horus the Behdetite, The JEA, Vol. 30, 23-60.

- Harrell, J.A., L. Lazzarini and M. Bruno, (2000), Reuse of Roman ornamental stones in medieval Cairo, Egypt; in L. Lazzarini (ed.), ASMOSIA VI, Interdisciplinary Studies on Ancient Stone - Proceedings of the Sixth International Conference of the Association for the Study of Marble and Other Stones in Antiquity, Venice.

- Heiden D. 2001. Pharaonische Baumaterialien in der ayyubidischen Stadtbefestigung von Kairo, MDAIK 57, 59-72

- Heiden D. 2002. Pharaonische Baumaterialien in der mittelalterlichen Stadtbefestigung von Kairo, MDAIK 58, 257-75 
- Kitchen K. A 1984. Rameses V-IX in LÄ V 124-128.

- KRI: Kenneth A. Kitchen, Ramesside Inscriptions, Historical and Biographical. 8 vols. Oxford: Blackwell, 1975-91.

- LGG: Christian Leitz (ed.), Lexikon der ägyptischen Götter und Götterbezeichnungen (= Orientalia Lovaniensia Analecta, 110-116, 129), 8 vols., Leuven 2002-2003

- Leprohon Ronald J. 2013. The great name: ancient Egyptian royal titular. In Lewis Theodore J. (ed.) Writings from the Ancient World 33. Society of Biblical Literature, Atlanta.

- Lorand D. 2013. A block of Ramesses II reused as a threshold in the Wakala of Qawsun (Cairo). JEA 99, 270-272.

- Postel Lilian ; Regen Isabelle, (2005), Annales héliopolitaines et fragments de Sésostris Ier réemployés dans la porte de Bâb al-Tawfiq au Caire, BIFAO, no105, 229-293.

- Postel Lilian ; Regen Isabelle, (2006), Réemplois pharaoniques à Bâb al-Tawfiq, BIFAO106, 183-218.

- RITANC: Kenneth A. Kitchen, Ramesside Inscriptions, Translated \& Annotated, Notes and Comments.Vol. II. Oxford: Blackwell 1999.

- Simpson W. K. 1985. Sesostris I In LÄ V, col 890-899.

- Sotohy H. T. A. 2011, Re-used Pharaonic blocks in Cairo Islamic monuments. Journal of Association Arab Universities for Tourism and Hospitality. Vol. 8 Special Issue-Part 1.

- Meinecke-Berg V. 1982. 'Spolien in der mittelalterlichen Architektur von Kairo', in Deutsches Archäologisches Institut, Ägypten: Dauer und Wandel. Symposium anlässlich des 75 jährigen bestehends des Deutschen Archäologischen Instituts Kairo am 10. und 11. (SDAIK 18; Cairo, 1985), 133, 135, pl. 12c.

- Williams, C., (2008), Islamic Monuments in Cairo- The Practical Guide, Cairo, 2007.

- Wb: Erman, A., and Grapow, H., ed., Worterbuch der Aegyptischen Sprache. ed. Berlin, 1926-53. 


\section{مجلة اتحاد الجامعات العربية للسياحة والضيافة}

\section{(JAAUTH)}

المجلد 21، العدد 1، (ديسمبر 2021)، ص ص25:25-33.

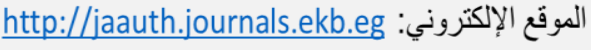

كتل فرعونية معاد استخدامها في آثار القاهرة الإسلامية الجزء الثاني

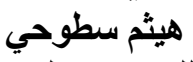

قسم الإرشاد السياحي، المعهد العالي للاراسات السيّاحية وادارة الفنادق (ايجوث)، الاقصر

\begin{tabular}{|c|c|}
\hline الملخص & معلومات المقالة \\
\hline 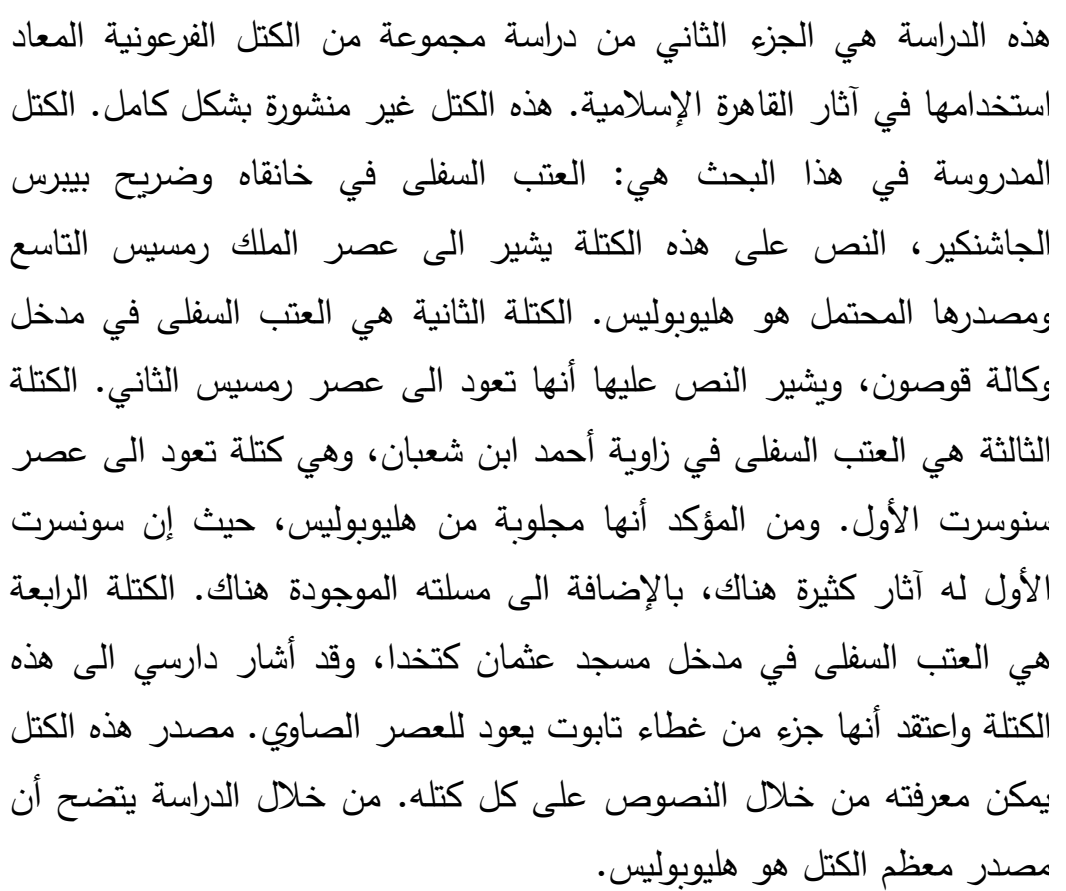 & 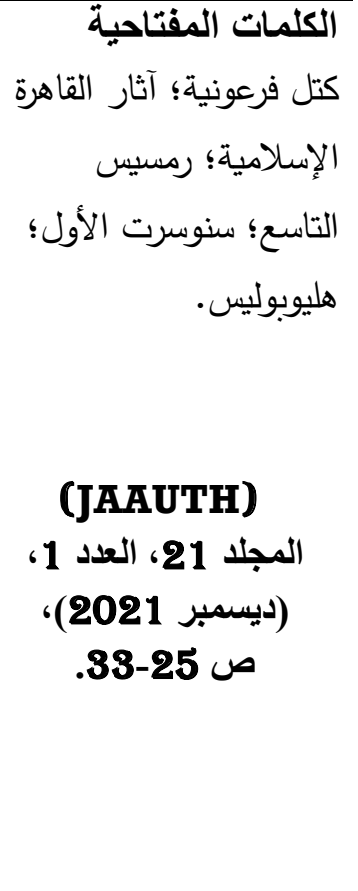 \\
\hline
\end{tabular}

